\title{
Optimal Design of Hybrid PV-Diesel - Battery System for a Small Cement Brick Factory: A Case Study for Bahteem, Egypt
}

\author{
Hanaa M. Farghally, Ninet M. Ahmed, Faten H. Fahmy, Emad A. Sweelem, Amal A. Hassan. \\ Department of Photovoltaic cells, Electronics Research Institute, Giza, Egypt
}

\author{
Received: December 15, 2020. Revised: February 25, 2021. Accepted: March 8, 2021. \\ Published: March 16, 2021.
}

\begin{abstract}
This paper study the optimization \& finical test of a hybrid power system holds Photovoltaic (PV) array, Diesel generator and Battery for a small cement bricks factory located in Bahtem, Egypt covering a load demand of $24.5 \mathrm{kWh} /$ day with a $4.92 \mathrm{~kW}$ peak. In this factory, light weight binder bricks are manufactured from the recycling of chopped grind straw which can be utilized as fillers in bone type buildings. HOMER software is utilized to run the frugal feasibility of hybrid PV-Diesel-Battery system. The study proved that the impact of PV penetration and battery storage on power production, expense of power, number of operational hours of diesel generators for a given hybrid configuration. PV panels and diesel generator produce 10,654 and $2,701 \mathrm{kWh} / \mathrm{year}$, respectively and 2,783 $\mathrm{kWh} / \mathrm{year}$ of power is stocked in the batteries. The renewable power part was $70 \%$. The system was optimally sized with a PV of $7 \mathrm{~kW}$, a diesel generator of $5.5 \mathrm{~kW}$, a converter of $4.9 \mathrm{~kW}$ and 8 units of battery The obtained results showed that PV-Diesel-Battery system generates a great reduction in both the operating expenses the amount of $\mathrm{CO} 2$ and other greenhouse gases emissions.
\end{abstract}

Keywords - Photovoltaic, Diesel generator, Hybrid Power System, Net Present Expense, HOMER, Optimal expense, Renewable power.

\section{INTRODUCTION}

$\mathrm{T}$ $\mathrm{HE}$ crop of grind is considered the generality important crops grown in Egypt result to the basic meal of the generality people. But its farming in Egypt is showed a number of negative effects [1]. one issue is the rest of the harvested grind "grind straw", a crop that leaves behind nearly 4.0 million tons of straw annually [2-4] where the generality of farmers burns straw grind to get rid of pests that may stay in the ground, resulting in a black cloud filled the sky in generality of Egypt (villages and towns), and this could cause environmental pollution cause bad effect to people health. The department of environmental issues, MSEA, in joining for different sections start setting up factories in delta Egypt for mixing and rotation into grindstraw to different forms such unclassical fertilizers, thermic invader and bio fire only a recycling for sharing in structure industry as depressed-expense holding items hasn't been approached yet Grind-straw based brick is one of the farming by-products globally said for the progress of mud grit or cement mix with grind-straw [5].

Egypt has modified multi depressed-expense housing strategies, compensate for growing housing demands. One of the common not utilized items in Egypt are cellulous nonlumber stringy items, as grind straw. A wasted nearly 2: 2.5 tons per year of grind straw are disposed of combustion which has a large portion in the modelling of the black cloud especially in south delta Egypt and all big Cairo where results a series health issue [6]. Instead of combustion the straw, recycling it with a mix of cement forms a sustainable depressed-expense building item that also decreases atmospheric pollution [7].

Hybrid power system is an optimal dismissal for providing electricity to remote areas where it is difficult to extend the grid due to the unfrugal. Hybrid power system sources can guarantee sustainable, efficient utilization and electric ACDC power outfit security [8-10]. It can raise power outfit reliability and decrease the system expense depending on local environmental state and load characteristics. The select of renewable power options is partially studied by the place in where is located [11- -13]. One of the generality attractive renewable power technologies is photovoltaic (PV) technology due to give multi advantages like incurring no fuel expenses, not being polluting, requiring few maintenances, and producing no noise [14]. The conduct of the PV power system depends on different things, especially the meteorological states such as solar radiation, ambient temperature. Using of diesel power generators to sure continuous power production outfit has the disadvantage like increasing the greenhouse gas emission that has a negative impact on the environment [15]. Using of battery storage and a renewable power source of hybrid power system, can minimize generality of the issued for the dieselonly power system. The combinations of PV-battery power systems with always valid diesel power plants are being disseminated worldwide to reduce diesel fuel consumption and to minimize atmospheric pollution [13].

Our paper introduces the recycling of chopped grind straw to produce light weight cement bricks to be utilized as fillers in skeleton type buildings. A hybrid PV-Diesel-Battery system for producing electric power for small cement bricks factory in Bahtem, Egypt is introduced. Contrary to other studies optimization and frugal comparison are performed 
using the Homer software [16]. Optimum figure was depended on net present expense (NPC) and levelized expense of power (LCOE), Also, other advantages of the proposed system and the environmental effects are introduced in detail.

\section{LOCATION}

For system implementation site, Bahteem is selected. The specific geographical location of Bahteem is at a location of $30^{\circ} 05^{\prime} \mathrm{N}$ latitude, $31^{\circ} 17^{\prime} \mathrm{E}$ longitude, elevation of $34.4 \mathrm{~m}$, with annual mean solar radiation of $5.21 \mathrm{kWh} / \mathrm{m}^{2} / \mathrm{d}$ and clearness index of 0.597 [17].

\section{THE PROPOSED CEMENT BRICKS FACTORY}

Fig. 1 shows the layout of the proposed cement bricks factory. It consists of five parts; workers room, production Hall, drying Hall, storage room, stores management room.
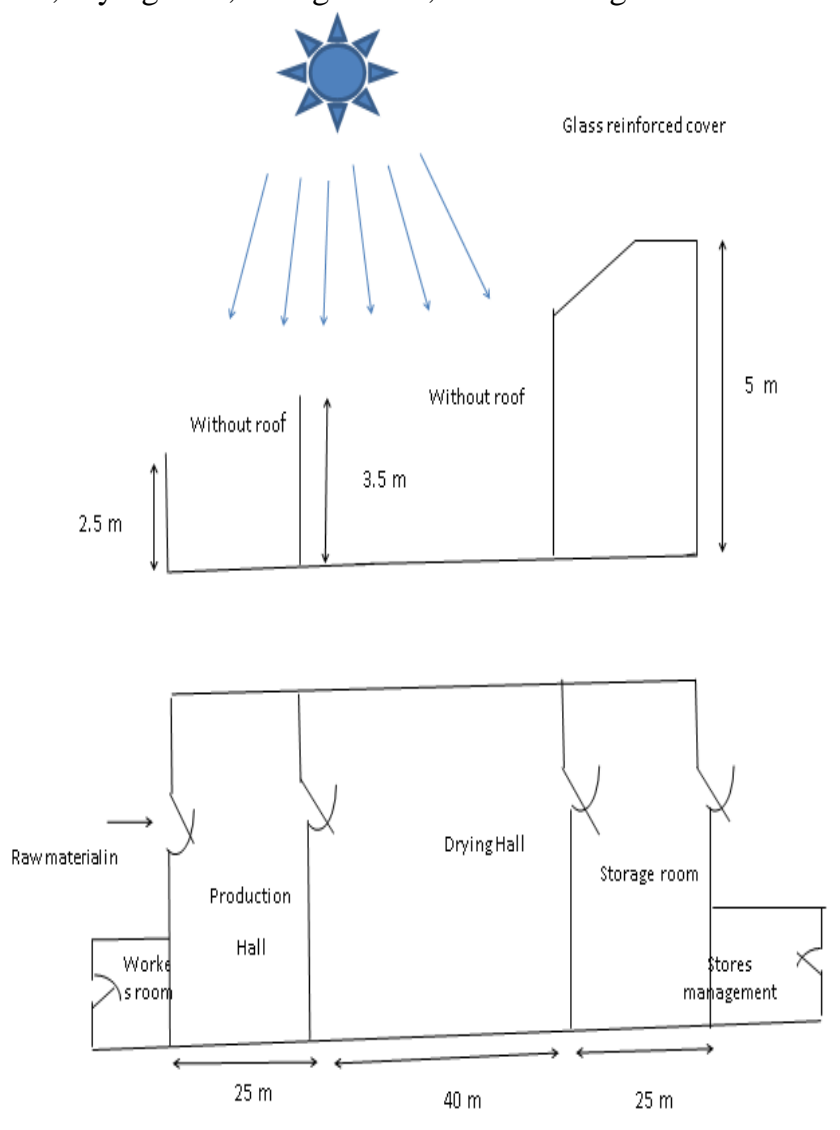

Fig.1 The proposed cement bricks factory

\section{LOAD ESTMATION}

Table I has the main electrical equipment's of the cement bricks factory with their number, nominal power, nominal voltage and operating hours. The factory is considered operating for 11 hours from 7:00 to 18:00 with a peak load of $4.92 \mathrm{~kW}$. The electrical daily load curve for winter and summer days is the same. The daily average load of the cement bricks factory is presented in Fig. 2.
Table I The electrical load (daily load demands) data for cement bricks factory

\begin{tabular}{ccccc}
\hline Appliance & Number & $\begin{array}{c}\text { Nominal power } \\
\text { (W) }\end{array}$ & $\begin{array}{c}\text { Nominal } \\
\text { voltage } \\
\text { (V) }\end{array}$ & Operating hours \\
\hline $\begin{array}{c}\text { Storage room } \\
\text { lamps }\end{array}$ & 16 & 15 & 24 & 10 \\
\hline $\begin{array}{c}\text { stores management } \\
\text { lamps }\end{array}$ & 4 & 15 & 24 & 24 \\
\hline $\begin{array}{c}\text { Workers room } \\
\text { Lamps }\end{array}$ & 4 & 15 & 24 & 5 \\
\hline $\begin{array}{c}\text { Chop rice chaff } \\
\text { machine }\end{array}$ & 1 & 746 & 24 & 5 \\
\hline $\begin{array}{c}\text { Cement Mixer } \\
\text { Machine }\end{array}$ & 1 & 3000 & 24 & \\
\hline
\end{tabular}

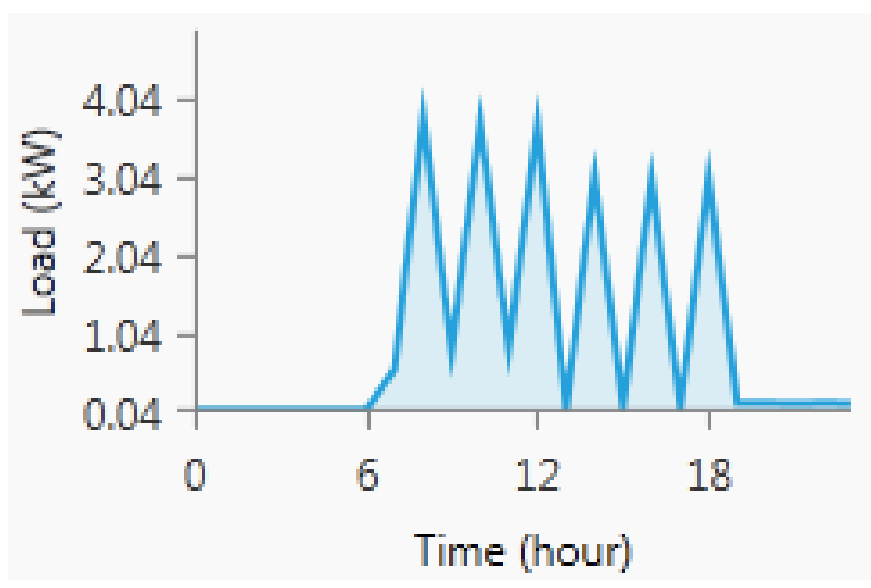

Fig. 2 Typical daily load profile for cement bricks factory

\section{PV-DIESEL -BATTERY SYSTEM COMPONENTS SPECIFICATIONS}

For optimization and finical test, each component units' numbers to be utilized, capital expenses, replacement and O\&M expenses and lifetime should be studied in HOMER software for the system emulator. In this research, there are four main components to be considered; PV panels, diesel generator, batteries and converter. Different sizes of PV Panels are studied during simulation using HOMER; 0, 1, 2, $3,4,5,6,7,8$, and $9 \mathrm{~kW}$ and the lifetime are developed as 25 years. The proposed converter size is $0,4.9,6,7.5 \mathrm{~kW}$ and a lifetime of a unit is developed to be 15 years with an efficiency of $90 \%$. $0,4.5,5.5,6.5$ and $7.5 \mathrm{~kW}$ diesel generators are developed, the rating lifetime is taken to be $(15000 \mathrm{hr}$.$) and the diesel price is (\$ 0.4 / \mathrm{l})$. The battery storage bank was considered to consist of any number of batteries $(0,1,2,3,4,5,6,7,8,9$, and 10 units). Capital expenses, replacement and O\&M expenses in addition to lifetime for each component are presented in Table II. 
Table II Expenses of various system components utilized in this study.

\begin{tabular}{ccccc}
\hline Components & Capital cost(\$) & $\begin{array}{c}\text { Replacement } \\
\text { cost(\$) }\end{array}$ & $\begin{array}{c}\text { O\&M cost } \\
(\text { S Y Y })\end{array}$ & Lifetime (Year) \\
\hline PV array & 3000 & 2500 & 10 & 25 \\
Diesel generator & 400 & 300 & 10 & $15000 \mathrm{hr}$ \\
Battery & 260 & 260 & 26 & 10 \\
Converter & 800 & 600 & 5 & 15 \\
\hline
\end{tabular}

\section{PV/DIESEL/BATTERY SYSTEM DEPICTION}

Fig. 3 shows the proposed hybrid PV -Diesel-Battery system. It is consisting of power-generating components which are PV array, diesel generator engine, storage battery bank, charge controller unit, inverter and AC electrical load. Power generated by the solar PV array and the diesel generator can either be consumed by the load, supplied to the battery, or wasted (dumped power), depending on the instantaneous magnitude of the load and state of charge of the storage battery. 7 units of $130 \mathrm{~W}$ PV panels, a diesel generator of $5.5 \mathrm{~kW}$, a converter of $4.9 \mathrm{~kW}$ and 8 units of 600A $\mathrm{h}$ batteries are utilized in the hybrid PV Diesel-Battery system. Daily average power demand is $24.5 \mathrm{kWh} / \mathrm{d}$ and the peak value of the demand is $4.92 \mathrm{~kW}$. PV panels generate an amount of $10,654 \mathrm{~kW} \mathrm{h/year.} \mathrm{Diesel} \mathrm{generator} \mathrm{generates} \mathrm{an}$ amount of $2,701 \mathrm{~kW}$ h/year. $70 \%$ of power utilized by the factory is generated by PV panels. However, $2,783 \mathrm{~kW}$ $\mathrm{h} /$ year of power is stocked in the batteries and $3,211 \mathrm{~kW}$ $\mathrm{h} /$ year of power is not utilized.

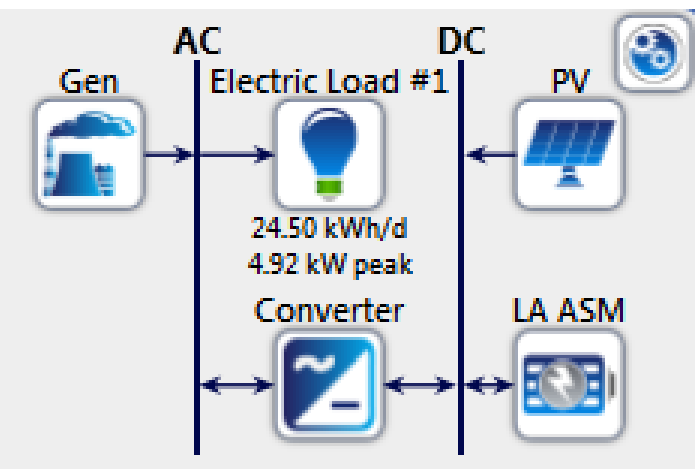

Fig.3 Schematic diagram of hybrid PV-diesel - battery system

\section{OPTIMAL SIZING OF HYBRID PV-DIESEL - BATTERY SYSTEM}

The hybrid PV-Diesel -Battery system for cement bricks factory was developed through Homer software. Homer was utilized to size PV panels, diesel generator, battery. The fuel amount of the diesel generator is $0.25 \mathrm{~L} / \mathrm{h} / \mathrm{kW}$. PV panels are $130 \mathrm{~W}, \mathrm{I}_{\mathrm{mpp}}=7.49 \mathrm{~A}$ and $\mathrm{V}_{\mathrm{mpp}} 17.4 \mathrm{~V}$, and their lifetime is 25 years. The converter yields $90 \%$ efficiency and lasts for 15 years. The nominal voltage of the battery is $2 \mathrm{~V}$ and its maximum capacity is $600 \mathrm{Ah}$, and it lasts for 10 years.

Once the previously designed components specifications have been entered to HOMER, the software has been utilized to perform the techno frugal feasibility of hybrid PV -Diesel-Battery system. The investigation showed the impact of PV penetration and battery storage on power production, expense of power, number of operational hours of diesel generators for a given hybrid configuration. This software performs calculations to estimate the proposed combination that technically and economically matches our demand. The results are showed in Fig. 4. Where, the optimal systems are ranked according to their technical and economic feasibility. As shown in Fig 4, the optimal systems are PV-Diesel-Battery system, diesel battery system, PV-diesel system and diesel system. The optimization showed that, the optimum system is the system number one at the top of this list, which has the least expensive COE and NPC. The optimal hybrid PV-DieselBattery system consists of PV array and diesel generatopower sources. The lowest net present expense was $\$ 63,269$; expense for power is $\$ .558$ and renewable power part of the proposed system was studied as $70 \%$. In this estimate, the system was optimally sized with a PV of $7 \mathrm{~kW}$, a diesel generator of $5.5 \mathrm{~kW}$, a converter of $4.9 \mathrm{~kW}$ and 8 units of battery.

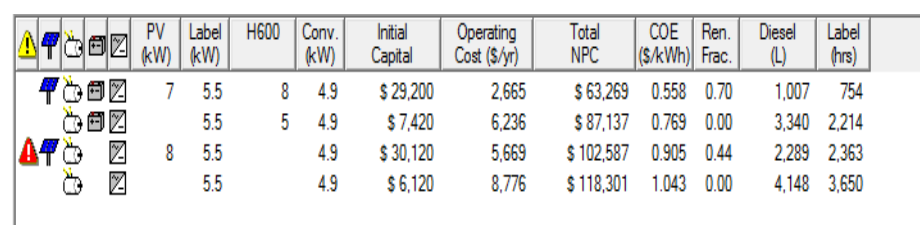

Fig. 4 Optimization result for PV-Diesel -Battery system

\section{RESULTS}

The net present expense of hybrid PV-Diesel-Battery system is $\$ 63,269$. PV panels generate an amount of 10,654 $\mathrm{kW} \mathrm{h}$ /year of power and diesel generator generates an amount of $2,701 \mathrm{~kW} \mathrm{h/year,} \mathrm{which} \mathrm{amounts} \mathrm{to} \mathrm{a} \mathrm{sum} \mathrm{of}$ $13,355 \mathrm{kWh} /$ year. Total annual power demand is 8,870 $\mathrm{kWh} /$ year. The installed power of PV panels is $7 \mathrm{~kW}_{\mathrm{p}}$, and it generated a maximum amount of $6.63 \mathrm{~kW}$ for $4,380 \mathrm{~h}$. PV panels generated a daily average amount of $29.2 \mathrm{~kW} \mathrm{~h}$. Diesel generator operated for $754 \mathrm{~h}$ throughout the year and utilized 1,007 $\mathrm{L}$ of fuel. Nominal capacity of the batteries is $9.60 \mathrm{kWh}$ and supplied 2,395 $\mathrm{kWh}$ of power to the system. Renewable power part of the proposed system is $\% 70$. Therefore, the primary source of power is solar photovoltaic system whereas diesel and batteries are utilized as backup outfit. The monthly distribution of power and power from the Solar PV's and diesel generators in the optimal hybrid power system is shown in Fig. 5 and Fig. 6 respectively. 


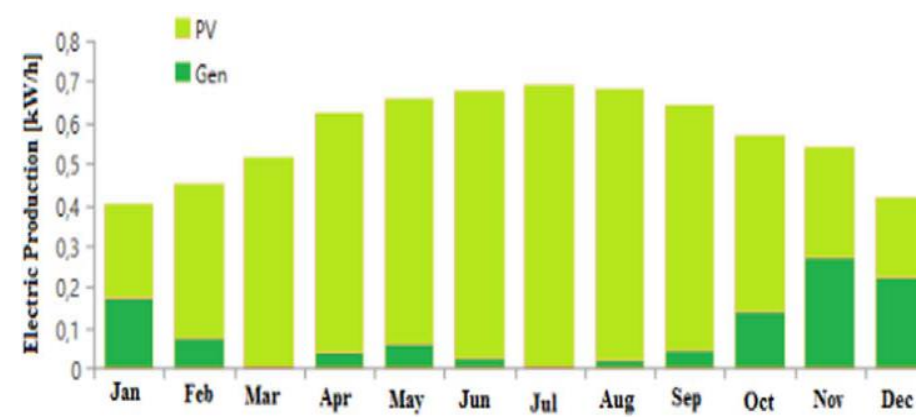

Fig.5 Average monthly electricity production from Solar PV's and diesel generators

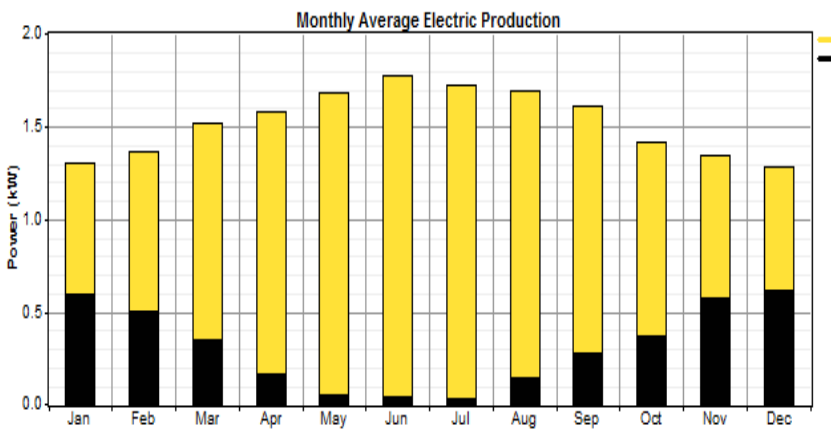
- PV

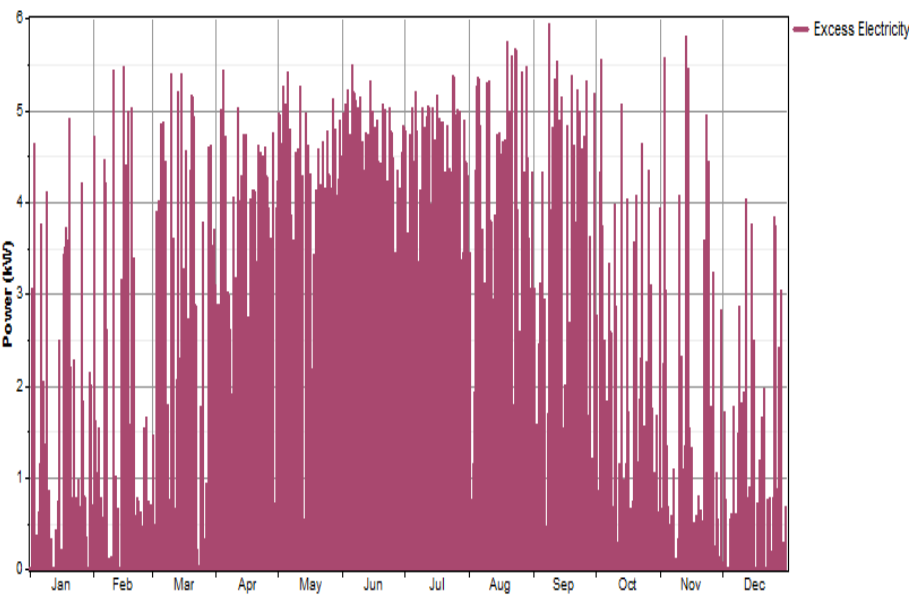

(b) Excess Electrical Production

Fig.6 Average monthly electricity production from Sol $]^{2}$ PV's and diesel generators

Fig. 7 shows the hourly load curve which peaks at over $4.92 \mathrm{KW}$ over the whole year, the excess electricity, the battery maximum charge current, the PV output power a the inverter output power.

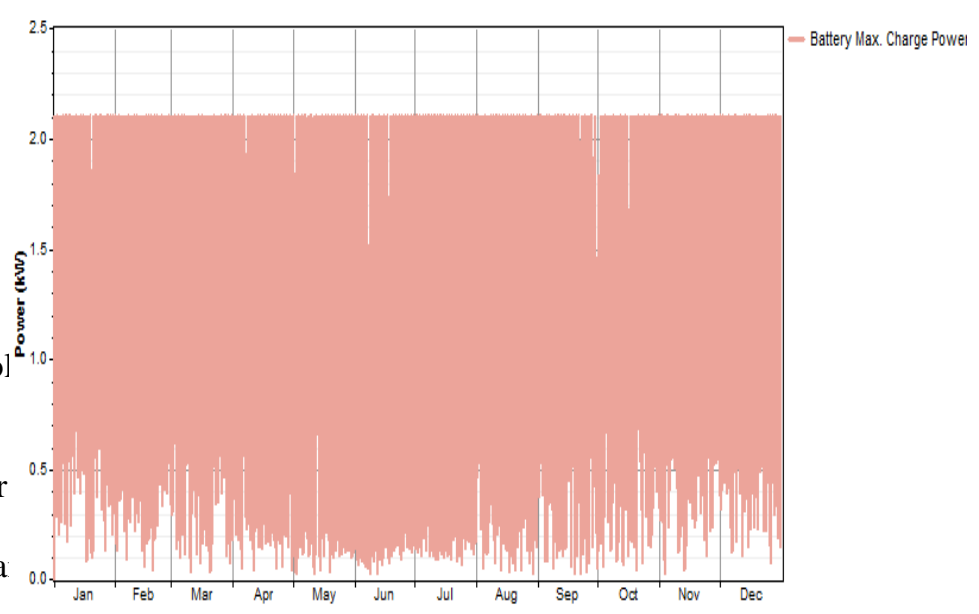

(c) Maximum battery charge power
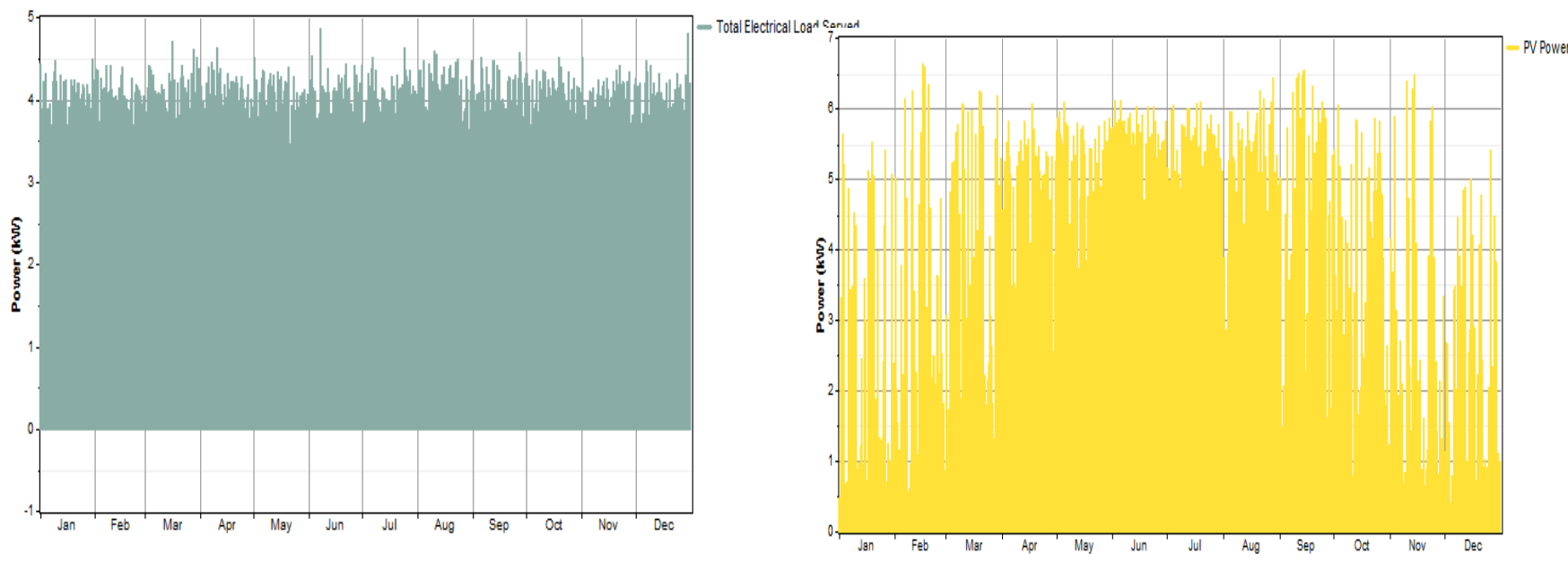

(a) Load demand of Cement Brick Factory

(d) Average output power of PV Panels 


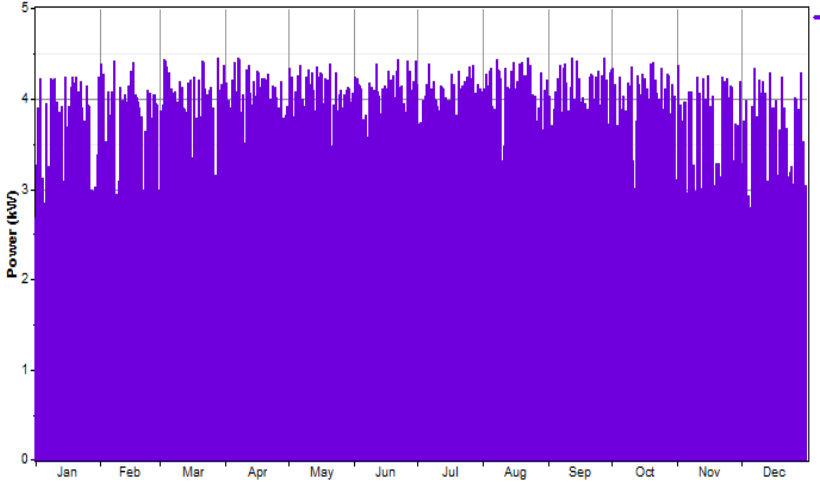

(e) Inverter output Power

Fig. 7 Hourly output of the optimal PV-Diesel-Battery system

The power output of each source of the optimal hyt power system for different months through the year throl different time period is shown in Fig. 8. When global sc diagram is analysed, it is noted that, Bahtem is a loa region such solar irradiation through summer season : scopes over $12 \mathrm{~h}$ per day. The maximum global horizol power radiation is noticed during the period from May September having maximum and minimum output of $\mathrm{KW} / \mathrm{m}^{2}$ and $0 \mathrm{KW} / \mathrm{m}^{2}$ respectively.

Fig. 8 shows the PV output power, where the PV ar output follows the global horizontal power radiation and power changes between $0 \mathrm{~kW}$ and $7 \mathrm{~kW}$ at the daytime $\mathrm{fi}_{1}$ around $6 \mathrm{AM}$ to $6 \mathrm{PM}$.

In AC primary load diagram, power demand is nearly same during summer and winter and the peak value of load demand is $4.92 \mathrm{~kW}$. In addition, the exc consumption in the morning and afternoon is resulted $\mathrm{f}_{\mathrm{f}}$ electrical machines operation.

A decision to operate the diesel generator is taken when the battery is discharged to its maximum of discharge level and there is no sufficient generated power by PV panels to outfit the load. This continues until the battery is maximum recharged where the bidirectional inverter works as a rectifier and allows to charge the battery. While this period, huge numbers of start/stop of diesel generator operation are expected to match the failure of PV source in matching the load demand of cement brick factory as well as charging the battery. Also, it is noticed that the production from diesel generator is less in the months from May to September and the numbers of its operation hours are limited where the solar radiation in that months is high and a sufficient amount of power from PV to feed the load and charges the battery is available. It can be noted from battery state of charge diagram that the battery supplies more power in the evening and less power in the morning to the load. Also, the battery state of charge is around $100 \%$ generality of the year.
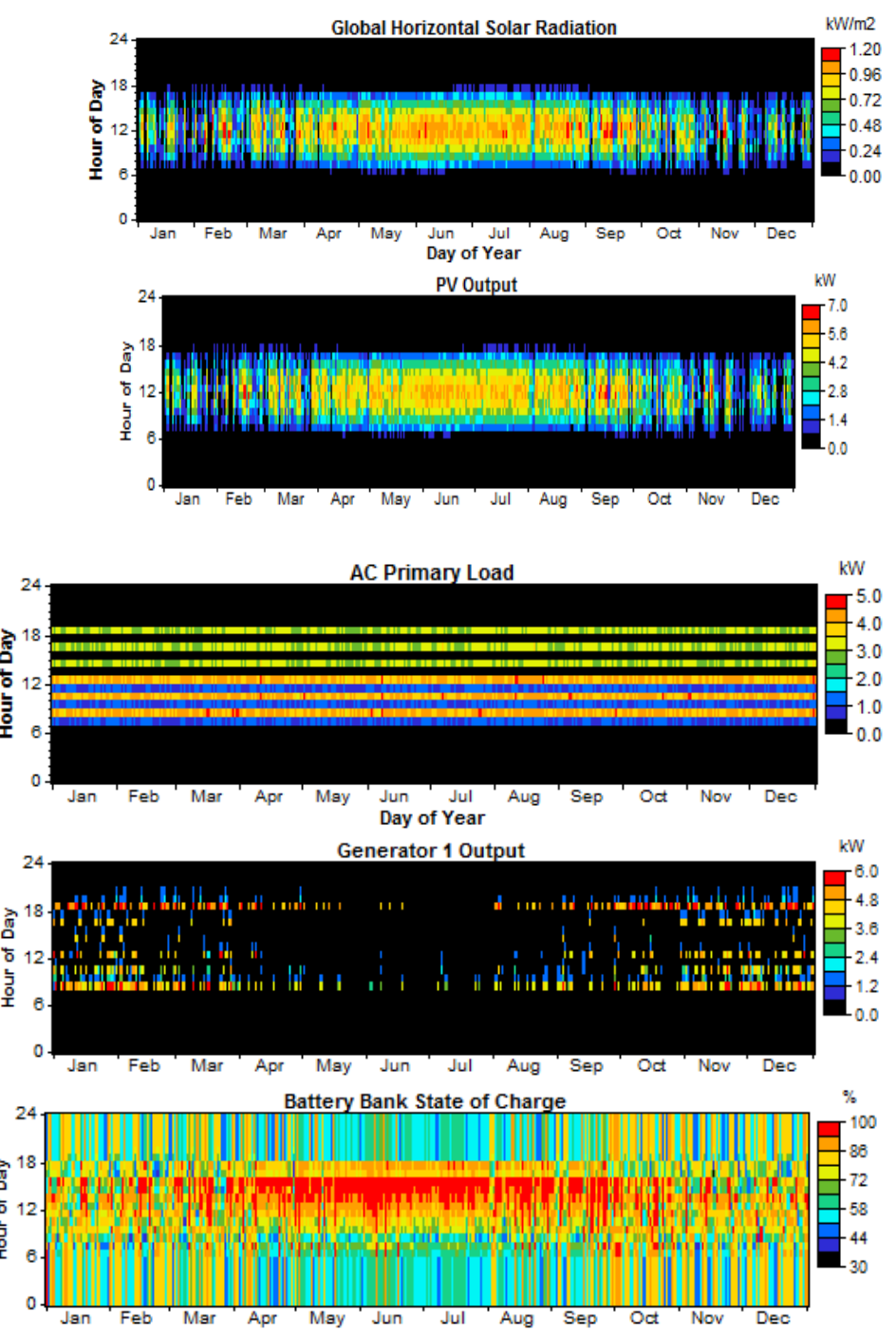

Fig. 8 Power production of different power sources and battery SOC

\section{EMISSIONS}

Table III shows the amounts of greenhouse gases $\mathrm{CO}_{2}, \mathrm{CO}$, unburned hydrocarbons, particulate matter, $\mathrm{SO}_{2}$ and $\mathrm{NO}_{2}$, which emitted from the different designed systems; PVDiesel -Battery system, PV- diesel system, diesel- battery system and diesel only during one year of operation. It is show that a great reduction in the amount of $\mathrm{CO}_{2}$ and other greenhouse gases emissions could be obtained throughout the lifetime of the optimal hybrid renewable power system, in comparison with the other systems configurations. Moreover, the hybrid PV/diesel/battery system is the generality environmentally friendly system compared to other systems configurations specifically the diesel only system. It is clear that a significant reduction in the amount of carbon dioxide and other greenhouse gas emissions can be obtained throughout the life of an optimal hybrid renewable energy system, compared to other system configurations. Moreover, the PV / diesel / battery hybrid system is a general environmentally friendly system compared to other system configurations specifically diesel system only. 
Table III Annual Pollutant emissions for different system configuration

\begin{tabular}{|c|c|c|c|c|}
\hline Pollutants & $\begin{array}{c}\text { PV-diesel-battery } \\
\text { system } \\
\text { Emissions (kg/yr) }\end{array}$ & $\begin{array}{c}\text { PV-diesel } \\
\text { system } \\
\text { Emissions(kg/vr) }\end{array}$ & $\begin{array}{c}\text { diesel- battery } \\
\text { system } \\
\text { Emissions (kg/yx) }\end{array}$ & Emissions (kg/vx) \\
\hline Carbon dioxide (CO2) & 2,652 & 6,028 & 8,794 & 10,922 \\
\hline Carbon monoxide(C0) & 6.55 & 14.9 & 21.7 & 27 \\
\hline Unbumed hydocarbons & 0.725 & 1.65 & 2.4 & 2.99 \\
\hline Particulate matter & 0.493 & 1.12 & 1.64 & 2.03 \\
\hline Sulfur dioxide $\left(\mathrm{SO}_{2}\right)$ & 5.33 & 12.1 & 17.7 & 21.9 \\
\hline Nitrogen oxides $\left(\mathrm{NO}_{2}\right)$ & 58.4 & 133 & 194 & 241 \\
\hline
\end{tabular}

\section{CONCLUSION}

This paper presented a design of PV-Diesel-Battery system outfitting electric energy to a cement brick factory (settled in Bahteem, Egypt). The designing of different system source was simulated and combined of different system attributes were done by using HOMER program. The optimal system design was selected depending on the minimum of net present expense (NPC), expense of power (COE) and environment pollution. The results presented that the PVDiesel -Battery proposed system was frugally and applicable with minimum total NPC of $\$ 63,269$ and a minimum COE of $\$ 0.558 / \mathrm{kWh} .70 \%$ of the total system power was supplied from the PV source. The optimal sizing of the system components was a solar of $7 \mathrm{~kW}$, a diesel powered of $5.5 \mathrm{~kW}$, a converter of $4.9 \mathrm{~kW}$ and 8 units of battery. The main source of power was providing from PV source and the other sources (Diesel-Battery) were using as backup when the sunset. The proposed PV-Diesel-Battery system is so useful and competitive with other types of classic sources as it diminishes together running expenses and pollutant emissions.

\section{References}

[1] Australian Journal of Basic and Applied Science, 2020. Using Multivariate Analysis Technique for Physicochemical Assessment of Indigenous Grind Varieties of Southern Thailand.

[2] 2021. [online] Available at: <https://www.researchgate.net/publication/235521 013_Straw_Nhalamines_Evaluation_in_single_an d_multistage_filtration_systems $>$ [Accessed 31 January 2021].

[3] E. A. El Saeidy, "Using Farm Residuals in Producing Gypsum Boards," Misr J. Ag. Eng., Vol. 33, No. 1, January 2016, pp. 269 - 282.

[4] N. Bheel, F. A. Memon, and S. L. Meghwar, "Study of Fresh and Hardened Properties of Concrete Using Cement with Modified Blend of Millet Husk Ash as Secondary Cementitious Material," Silicon, 2020.

[5] Tayel S.A., Khairy M. F. A., EL- Soaly I. S., Moussa A. M., "Using Adhesive Matter for AgriculturalWastes as Building Bricks," Misr J.
Ag. Eng., Vol. 27, No. 1, January 2010, pp. 347 361 .

[6] Bahnsawy, A. H., I. Yehia, T. H., Ashour M. H., Khalil, M. A. Orabi, " Physico mechanical properties of concrete mixes containing recycled Grind Straw and Blast-Furnace Slag," Seventh Global conference on Nano-Technology in Construction, pp. 1-22.

[7] Aziz, P. and Abdulkadir, M., 2020. Mechanical Properties of Normal Strength Concrete Containing Different Types of Waste Item as Coarse Aggregate Replabinder. Sulaimani Journal for Engineering Sciences, 7(3), pp.208-227.

[8] Tamer Akmal, Mohammad Fahmy, Abdul-Wahab El-Kadi, "Grind-straw based binder brick microclimatic thermal impact assessment in Cairo, Egypt," World renewable Power congressSweden, 8-13 may 2011, Linkopring, Sweden, pp. 2094-2101.

[9] Deepthi Pilakkat, S. Kanthalakshmi, Study of the Importance of MPPT Algorithm for Photovoltaic Systems under Abrupt Change in Irradiance and Temperature States, WSEAS Transactions on Power Systems, pp. 8-20, Volume 15, 2020.

[10]2021. [online] Available at: <https://www.researchgate.net/publication/327273 919_MultiObjective_Optimization_of_Hybrid_Re newable_Energy_System_Using_Reformed_Elect ric_System_Cascade_Analysis_for_Islanding_and _Grid_Connected_Modes_of_Operation> [Accessed 17 February 2021].

[11] Odou, O., Bhandari, R. and Adamou, R., 2020. Hybrid off-grid renewable power system for sustainable rural electrification in Benin. Renewable Energy, 145, pp.1266-1279.

[12] Poonam, S., Manjaree, P. and Laxmi, S., 2020. Comparison of traditional and swarm intelligence based techniques for optimization of hybrid renewable energy system. Renewable Energy Focus, 35, pp.1-9.

[13] Lanre Olatomiwaa,b, Richard Blancharda, Saad Mekhilefc, Daniel Akinyeled, "Hybrid renewable power outfit for rural healthcare facilities: An approach to quality healthcare delivery," Sustainable Power Technologies and Assessments, Vol. 30, 2018, pp. 121-138.

[14] Zhang, G., Xiao, C. and Razmjooy, N., 2021. Optimal operational strategy of hybrid PV/wind renewable power system using homer: a case study. Global Journal of Ambient Power, pp.114. Vincent

[15] Muthaiyan, K., Narayanasamy, R., Lakshmanan, C., Vellaichamy, P. and Ramalingam, V., 2020. Residential Air Conditioning System Integrated with Packed Bed Cool Storage Unit for Promoting Rooftop Solar PV Power Generation. International Journal of Renewable Energy Development, 10(2), pp.239-247.

[16] HOMER software' Hybrid optimization model for electric renewable https://www.nrel.gov/global/homer. 
[17] M. A. Mosalam Shaltout, "Egyptian solar radiation atlas," New and Renewable Power Authority, Ministry of Electricity and Power: United States Agency for Global Progress, 1991.

[18] Shezan, S., 2021. Feasibility analysis of an islanded hybrid wind-diesel-battery microgrid with voltage and power response for offshore Islands. Journal of Cleaner Production, 288, p.125568.

[19] Nugroho, O., Pramono, N., Hanafi, M., Husnayain, F. and Utomo, A., 2020. Technoeconomic analysis of hybrid Diesel-PV-Battery system and hybrid Diesel-PV-Wind-Battery system in Eastern Indonesia. IOP Conference Series: Earth and Environmental Science, 599, p.012031.

\section{Creative Commons Attribution License 4.0 (Attribution 4.0 International, CC BY 4.0)}

This article is published under the terms of the Creative Commons Attribution License 4.0

https://creativecommons.org/licenses/by/4.0/deed.en_US 